NBER WORKING PAPER SERIES

BACKING, THE QUANTITY THEORY, AND THE TRANSITION TO THE U.S.

DOLLAR, 1723-1850

Peter L. Rousseau

Working Paper 12835

http://www.nber.org/papers/w12835

\author{
NATIONAL BUREAU OF ECONOMIC RESEARCH \\ 1050 Massachusetts Avenue \\ Cambridge, MA 02138 \\ January 2007
}

The views expressed herein are those of the author(s) and do not necessarily reflect the views of the National Bureau of Economic Research.

(C) 2007 by Peter L. Rousseau. All rights reserved. Short sections of text, not to exceed two paragraphs, may be quoted without explicit permission provided that full credit, including $\odot$ notice, is given to the source. 
Backing, the Quantity Theory, and the Transition to the U.S. Dollar, 1723-1850

Peter L. Rousseau

NBER Working Paper No. 12835

January 2007

JEL No. E31,E42,N11

\begin{abstract}
$\underline{\text { ABSTRACT }}$
Among the thirteen original colonies, Pennsylvania was most successful at issuing paper money with only minimal effects on prices -- so much so that the colony's experience is sometimes seen as violating the classical quantity theory of money. Quantity theorists usually attribute this apparent anomaly to mismeasurement of the money stock. In contrast, I use data on money, prices, and real activity in Pennsylvania from 1723 to 1774 and for the United States as a whole from 1790 to 1850 (when the money stock is better measured) to show that the long-run behavior of money and prices is well explained by the quantity theory in both periods, despite the differences in institutional arrangements, once growth in monetized transactions is taken into account.
\end{abstract}

Peter L. Rousseau

Department of Economics

Vanderbilt University

Box 1819 Station B

Nashville, TN 37235

and NBER

peter.1.rousseau@vanderbilt.edu 


\title{
Backing, the Quantity Theory, and the Transition to the U.S. Dollar, 1723-1850
}

\author{
By Peter L. Rousseau *
}

Prior to the ratification of the Federal Constitution and adoption of the dollar standard nationwide, the thirteen original colonies operated under monetary systems that differed significantly from the one that followed. Among these, Pennsylvania was most successful at issuing paper money with only minimal effects on prices -- so much so that the colony's experience is sometimes seen as violating the classical quantity theory of money, that is, the identity

(1) $\quad \mathrm{MV}=\mathrm{PY}$,

where $M$ is the nominal money stock, $V$ its velocity, $P$ the price level, and $Y$ real monetized transactions. Quantity theorists generally focus on the left-hand side of (1) when dismissing this apparent anomaly as resulting from mismeasurement of $M$ (Ronald Michener, 1987; Bennett T. McCallum, 1992). In contrast, this study emphasizes the right-hand side in faulting the assumption of a constant $Y$. Specifically, I use data on money, prices, and real activity in Pennsylvania from 1723 to 1774 and for the nation as a whole from 1790 to 1850 (when $M$ is better measured) to show that the long-run behavior of money and prices is well explained by (1) in both periods despite the differences in institutional arrangements.

The analysis is in the spirit of Robert E. Lucas (1980), who controlled for short-run effects while isolating the relationship between money and prices in postwar U.S. data, but

\footnotetext{
* Department of Economics, Vanderbilt University, Nashville, TN 37235, USA, and National Bureau of Economic Research. I thank Jeremy Atack and Boyan Jovanovic for comments.
} 
differs in bringing the effects of a growing modern sector back into the empirics at a time when accounting for them is crucial. How Pennsylvania money held its value in the short term is another matter, but I observe that the "backing" theory (Bruce D. Smith, 1985) seems ready to explain the data without requiring large stocks and flows of circulating specie money. My view thus offers some common ground among the quantity and backing theories.

\section{Background}

Before the Revolutionary War, various foreign coins passed from hand to hand as currency, supplemented by assorted fiat paper monies issued by individual colonial legislatures that sometimes also passed current beyond their borders. There is disagreement about how important coins were to the total money supply, with estimates ranging from as little as one-fifth to as much as two-thirds of it on average. Though this means that the quantity theory cannot be tested for the colonies with the total money stock, scholars have still noted low correlations between prices and outstanding stocks of paper money.

Indeed, assuming $V$ and $Y$ are constant in the short term, as per the usual starting point for the quantity theorists, Roger C. West (1978) found no statistical relationship between paper money and prices with the available data for the colonies of New York, Pennsylvania, and South Carolina. Michener (pp. 236-7) observed the absence of specie in the money stock of West's regressions and reasoned that if this potentially large component were included and were to fluctuate so as to offset paper money issues and retirements, the quantity theory would still hold. I contend that new paper issues, rather than causing perfectly offsetting specie outflows, could have been absorbed without inflation in so far as they encouraged more transactions (i.e., $Y$ ) to 
be made using money. Since money was more efficient than barter or bookkeeping, its issuance not only drew transactions into the formal economy, but may have also increased activity therein.

The colonial economy certainly grew intensively over the period studied. John J. McCusker's essay in the Historical Statistics of the United States (Susan B. Carter et al., 2006, Vol. 5, pp. 630-31) suggests average annual per capita income growth of 0.6 percent between 1655 and 1775 , with more rapid growth between 1740 and 1774 . But even these estimates, though substantial by the standards of the time, understate how much the modern sector grew. For example, Pennsylvania's real exports to and total trade with England increased at average annual rates of 16.8 and 16.7 percent, respectively, between 1723 and 1774. Per capita output grew more quickly in the nation as a whole from 1790 to 1850 , and real exports and total trade grew at average annual rates of 11.8 and 11.7 percent, respectively, despite the export embargo of 1807-09. This is why it is necessary to control for $Y$ explicitly when exploring the relationship between money and prices in colonial and early U.S. history. To his credit, John Webbe (1743, p. 6) seemed unconfused when he wrote that "the value of it (i.e., paper money) will, on a supposition of its quantity continuing the same, be more or less in proportion to the intrinsic worth of the moveable commodities exchanged by it."

\section{Empirics}

The empirics proceed as follows: first, I show that traditional tests of the quantity theory "fail" for the United States as a whole between 1790 and 1850 in much the same way as they do for colonial Pennsylvania. This occurs even though we have much more complete data for the total money supply (i.e., paper and specie) for the later period and despite the absence of a system of government-issued fiat monies at that time. Then, assuming $V$ constant, I proxy for $Y$ using real exports and demonstrate that a long-run relationship, consistent with the quantity 
theory, exists between $Y$ and $M / P$ in both periods. Since $Y$ represents monetized transactions rather than aggregate output and such transactions were more prevalent in modern sectors such as shipping and international commerce than traditional ones, trends and fluctuations in real exports, even those associated with declining transport costs, would seem to provide the best available combined indicator of the demand for money and the economy's ability to absorb it.

Table 1-West-Style Regressions of Prices on Money

\begin{tabular}{|c|c|c|c|c|c|c|}
\hline \multirow[b]{2}{*}{ Constant } & \multicolumn{3}{|c|}{ Philadelphia Prices 1723-1774 } & \multicolumn{3}{|c|}{ U.S. Prices 1790-1850 } \\
\hline & $\begin{array}{l}4.235^{* *} \\
(0.409)\end{array}$ & $\begin{array}{l}4.021^{* *} \\
(0.549)\end{array}$ & $\begin{array}{l}3.946^{*} \\
(0.621)\end{array}$ & $\begin{array}{c}0.084 \\
(0.262)\end{array}$ & $\begin{array}{l}-0.318 \\
(0.396)\end{array}$ & $\begin{array}{l}-0.554 \\
(0.483)\end{array}$ \\
\hline $\mathrm{M}_{\mathrm{t}}$ & $\begin{array}{c}0.034 \\
(0.035)\end{array}$ & $\begin{array}{l}-0.052 \\
(0.047)\end{array}$ & $\begin{array}{l}-0.052 \\
(0.053)\end{array}$ & $\begin{array}{l}-0.009 \\
(0.049)\end{array}$ & $\begin{array}{c}0.007 \\
(0.050)\end{array}$ & $\begin{array}{l}-0.007 \\
(0.056)\end{array}$ \\
\hline $\mathrm{M}_{\mathrm{t}-1}$ & & $\begin{array}{l}0.114^{* *} \\
(0.036)\end{array}$ & $\begin{array}{c}0.090 \\
(0.060)\end{array}$ & & $\begin{array}{c}0.068 \\
(0.051)\end{array}$ & $\begin{array}{c}0.081 \\
(0.052)\end{array}$ \\
\hline $\mathrm{M}_{\mathrm{t}-2}$ & & & $\begin{array}{c}0.032 \\
(0.038)\end{array}$ & & & $\begin{array}{c}0.052 \\
(0.056)\end{array}$ \\
\hline Regression $\mathrm{R}^{2}$ & 0.00 & 0.14 & 0.09 & 0.00 & 0.04 & 0.08 \\
\hline Durbin-Watson & 1.56 & 1.59 & 1.59 & 1.53 & 1.59 & 1.55 \\
\hline
\end{tabular}

Table 1 presents West-style regressions that correct for first order serial correlation via maximum likelihood. ${ }^{1}$ For colonial Pennsylvania, I use annual averages of Arthur H. Cole's (1938, Table 48, pp. 138-9) index of monthly wholesale commodity prices for Philadelphia and the stock of paper money from Historical Statistics (2006, Vol. 5, Series Eg307, pp. 692-3). For 1790-1850, I use the consumer price index from Historical Statistics (Vol.3, Series Cc2, p.158) and the total money stock from Rousseau and Richard Sylla (2005, p. 22-4). There is little

${ }^{1}$ Standard alternative corrections for AR1 and AR2 disturbances yielded similar qualitative results. Box-Ljung "Q" statistics showed no indication of higher order serial correlation. 
evidence of correlation between the logs of prices and either contemporaneous or lagged money in either period. The lack of support for the quantity theory for 1790-1850 offers reason for pause since the proper measurement of $M$ renders the classical explanation for the failure of West's regressions inapplicable to the early Federal period. Indeed, it even seems that the quantity theory is better supported in the data for colonial Pennsylvania (see col. 2 of Table 1), which excludes the specie component of the money stock.

Maybe a short-run relation between money and prices that does not account for increases in monetized transactions or growth of the modern economy is just too much to expect from the quantity theory for 18th and early 19th century America. But does the quantity theory hold in the long-run? If so, we might expect to find a cointegrating relation between $Y$ and $M / P$ after rearranging (1).

Table 2 presents Soren Johansen's trace and maximum eigenvalue $(\lambda$-max) statistics for the corresponding bivariate autoregressive systems with three lags as determined by nested likelihood ratio tests. For colonial Pennsylvania, I use real exports to England from Historical Statistics (Vol. 5, Series Eg432, pp. 710-11) to proxy for $Y$; for 1790-1850 I use total exports and re-exports of merchandise (Vol. 5, Series Ee365, pp. 498-9) deflated by the export price index (Vol. 5, Series Ee431, pp. 515-16). M/P is formed by dividing the series for outstanding bills of credit and the total money stock by the corresponding commodity price indices. ${ }^{2}$ The test statistics reject the null hypothesis of no cointegration $(r=0)$ at the 10 percent level or better for both systems, while the null of at most one cointegrating vector $(r \leq 1)$ is not rejected for either.

\footnotetext{
${ }^{2}$ Augmented Dickey-Fuller tests with a constant, trend, and four lags do not reject the null hypothesis of a unit root for exports or real money in either period.
} 
This implies the existence of a valid error correction representation with a single cointegrating vector. Table 2 includes estimates of these vector error correction models (VECMs) of the form

(2) $\Delta \mathrm{Y}_{\mathrm{t}}=\mu_{1}+\gamma_{1,1} \Delta \mathrm{Y}_{\mathrm{t}-1}+\gamma_{1,2} \Delta \mathrm{Y}_{\mathrm{t}-2}+\xi_{1,1} \Delta \mathrm{M} / \mathrm{P}_{\mathrm{t}-1}+\xi_{1,2} \Delta \mathrm{M} / \mathrm{P}_{\mathrm{t}-2}+\alpha_{1}\left(\beta_{1} \mathrm{Y}_{\mathrm{t}-1}+\beta_{2} \mathrm{M} / \mathrm{P}_{\mathrm{t}-1}\right)+\varepsilon_{1, \mathrm{t}}$

(3) $\Delta \mathrm{M} / \mathrm{P}_{\mathrm{t}}=\mu_{2}+\gamma_{2,1} \Delta \mathrm{Y}_{\mathrm{t}-1}+\gamma_{2,2} \Delta \mathrm{Y}_{\mathrm{t}-2}+\xi_{2,1} \Delta \mathrm{M} / \mathrm{P}_{\mathrm{t}-1}+\xi_{2,2} \Delta \mathrm{M} / \mathrm{P}_{\mathrm{t}-2}+\alpha_{2}\left(\beta_{1} \mathrm{Y}_{\mathrm{t}-1}+\beta_{2} \mathrm{M} / \mathrm{P}_{\mathrm{t}-1}\right)+\varepsilon_{2, \mathrm{t}}$

where $\beta_{1}$ and $\beta_{2}$ are loadings on $\mathrm{Y}$ and $\mathrm{M} / \mathrm{P}$ that form a linear stationary combination (i.e., the "error correction term" or ECT) and the $\alpha_{\mathrm{i}}$ measure the speed with which the dependent variables adjust to shocks that perturb the combination. The ECT enters the model as a single lag.

Table 2- Vector Error Correction Models

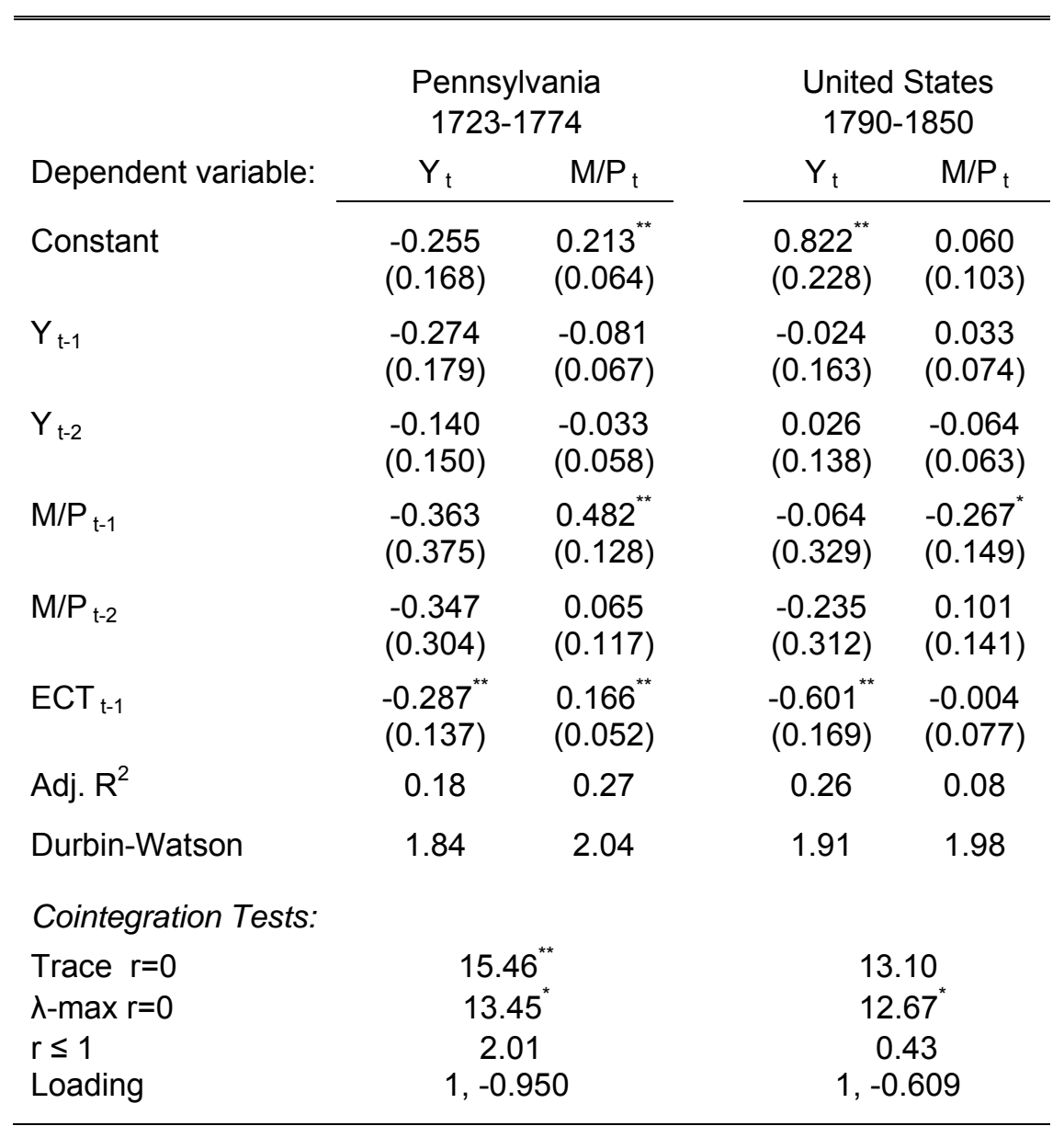

Note: All variables are in log levels. Asterisks denote statistical significance at the 10 percent $\left({ }^{*}\right)$ and 5 percent $\left({ }^{* *}\right)$ levels, respectively. 
For colonial Pennsylvania, the coefficients on the ECT (i.e., the $\alpha_{\mathrm{i}}$ 's) are significant at the five percent level in both equations of the VECM. The negative loading on the level of $M / P$ in the cointegrating vector (see final row of Table 2), combined with negative sign on $\alpha$ in the $Y$ equation implies that increases in $M / P$, which depressed the value of the stationary combination, were met with increases in $Y$. The $\alpha$ is positive in the $M / P$ equation, which combined with the positive loading on $Y$ suggests that increases in modern sector activity acted as an inducement for additional paper money issues. For 1790 to 1850 , the ECT is negative and significant only in the $Y$ equation. Combined with the negative loading on $M / P$, this once again suggests that increases in the real money stock tended to raise $Y$ in the long-run. The short-run parameters (i.e., the $\gamma_{i}$ 's and $\zeta_{\mathrm{i}}$ 's) are generally not significant in either period, except for the first lag of $M / P$ in the $M / P$ equations, which might be expected given that the coefficients of first-order autocorrelation for the $M / P$ series are 0.93 for $1723-1774$ and 0.98 for $1790-1850$.

\section{Discussion}

The findings of Section II support the long-run implications of the quantity theory. At the same time, the insignificant short-run parameter estimates in the VECMs raise the question of why prices did not increase more on impact given the quantities of paper money sometimes issued. For 1790-1850 one can argue that paper money was issued by banks and that individuals could most of the time present it to the issuer for redemption in specie, meaning that the young nation operated under fixed specie-paper exchange rates defended by individual banks. But who would have defended fixed rates in colonial Pennsylvania? Michener (p. 264) suggests that it was Philadelphia merchants, citing a set of coin ratings declared by 75 of them in the September 16, 1742 issue of the Pennsylvania Gazette as evidence, but it is hard to conceive of such groups controlling the value of exchange across an entire colony. McCusker's data on exchange rates 
between the British pound sterling and Pennsylvania pounds in Historical Statistics (2006, Vol. 5, series Eg318, p. 698) also indicate quite a bit of variation over time. Exchange rates could have fluctuated less than expected, however, if the specie stock was large enough for the public to deem paper as good.

The difficulty here is that the supply of specie appears to have been inadequate in Pennsylvania in the 1720s and 1730s, and perhaps throughout most of the colonial period. Indeed, this scarcity and the growing needs of commerce appear to have motivated the issuance of paper money in the first place (see Benjamin Franklin, 1729). There is an indication that the amount of specie in the colonies rose in the late 1740s with the end of King George's War, but also that these inflows were quickly reversed. We know for certain, however, that Pennsylvania increased its paper money stock more than five times over between 1755 and 1760 in the midst of the French and Indian War. How could the commodity price index have risen by only 15 percent in these years? Perhaps specie left the colony as the paper was issued, holding total money steady, but specie would have to compose about 80 percent of Pennsylvania's money supply in 1755 and nearly all of it would have to exit before 1761 to accomplish this, which seems extraordinary. Persistent inflows of coin from 1760 through 1773 would then have been necessary to maintain the total stock of money as the supply of paper fell by 70 percent, while if anything specie flows were erratic over this period.

Given these facts, we should consider carefully the model of Neil Wallace and Thomas J. Sargent (1982) as a possible explanation for the short-run stability of prices, especially after 1754. They show that money issues, if backed by "real bills," need not be inflationary. Building on this, Smith suggests that promises of colonial legislatures to accept paper money issues as loan and tax payments at some future date and then to destroy it effectively created an asset 
"backing" (i.e., a receivable) along with a liability (i.e., the paper money issue), leaving the colony's balance sheet unaltered. So long as the public maintained confidence that the government would adhere to these plans, modest new issues need not have been inflationary. Given Pennsylvania's early successes in issuing paper money, perhaps the "full faith and credit" of the government was something to be taken seriously by the time of the French and Indian War. This could have allowed the currency to retain its value until it could be reined back to more closely reflect the level of transactions sustainable after the war. In earlier years, such as 1729 when the stock of paper money rose by 77 percent, the backing theory can explain why the paper held its value while the colony's level of monetized transactions adjusted to it.

In any case, the "backing" versus "fixed rates" debate seems best suited to discussions of short-run phenomena. The quantity theory of money with the $Y$ properly accounted for, on the other hand, remains as equipped as ever to explain the long-run behavior of money and prices in colonial Pennsylvania, the early United States, and beyond.

\section{References}

Carter, Susan B.; Gartner, Scott Sigmund; Haines, Michael R.; Olmstead, Alan L; Sutch, Richard, and Wright, Gavin, eds. Historical statistics of the United States: Earliest times to the present. Millennial Edition. New York: Cambridge University Press, 2006.

Cole, Arthur Harrison. Wholesale commodity prices in the United States, 1700-1861. Cambridge, MA: Harvard University Press, 1938.

Franklin, Benjamin. A modest inquiry into the nature and necessity of a paper currency. Philadelphia: The New Printing Office, 1729. 
Johansen, Soren. "Estimation and Hypothesis Testing of Cointegration Vectors in Gaussian Vector Autoregressive Models."Econometrica, 1991, 59(6), pp. 1551-80.

Lucas, Robert E., Jr. "Two Illustrations of the Quantity Theory of Money.” American Economic Review, 1980, 70(5), pp. 1005-14.

McCallum, Bennett T. "Money and Prices in Colonial America: A New Test of Competing Theories." Journal of Political Economy, 1992, 100(1), pp. 143-61.

Michener, Ronald. "Fixed Exchange Rates and the Quantity Theory in Colonial America." Carnegie-Rochester Conference Series on Public Policy, 1987, 27, pp. 233-308.

Rousseau, Peter L. and Richard Sylla. "Emerging Financial Markets and Early U.S. Growth.” Explorations in Economic History, 2005, 42(1), pp. 1-26.

Sargent, Thomas J. and Wallace, Neil. "The Real Bills Doctrine versus the Quantity Theory: A Reconsideration.” Journal of Political Economy, 1982, 90(6), pp. 1212-36.

Smith, Bruce D. "Some Colonial Evidence on Two Theories of Money: Maryland and the Carolinas." Journal of Political Economy, 1985, 93(6), pp. 1178-1211.

Webbe, John. A discourse concerning paper money. Philadelphia: Bradford, 1743.

West, Roger Craig. "Money in the Colonial American Economy." Economic Inquiry, 1978, 16(1), pp. 1-15. 